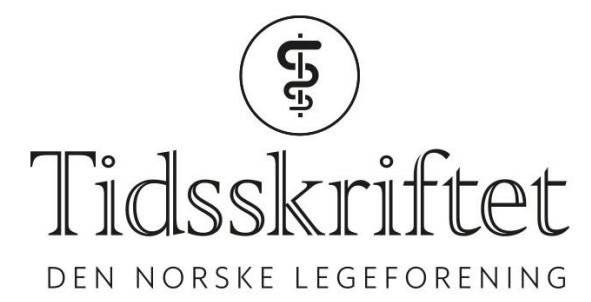

\title{
Värdebaserad vård - fågel, fisk eller kanske mitt i mellan
}

LEGELIVET

FREDRIK BÅÅTHE

LEFO-Legeforskningsinstituttet

Er värdebaserad vård ett pasientfokuserat koncept som vården behöver - eller ännu en kollektion av kejsarens nya kläder?

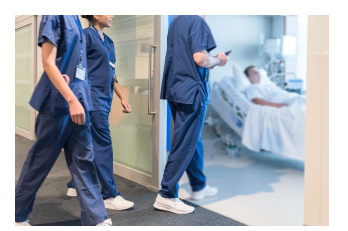

Illustrasjonsfoto:

JohnnyGreig/iStock

Värdebaserad vård är ett begrepp som lanserat av den amerikanske managementgurun Michael Porter från Harvard Business School. Tillsammans med Elisabeth Teisberg publicerade Porter 2006 boken Redefining Healthcare (1). Med värde menas bästa möjliga medicinska utfall för patienten, i relation till kostnaderna för att åstadkomma detta. I Sverige fick värdebaserad vård snabbt genomslag och de stora Universitetssjukhusen, Karolinska i Stockholm och Sahlgrenska i Göteborg var bland de första att påbörja en implementering.

Harvard professorn Porter ledde en två dagars konferens i Stockholm under november 2014. Där definierades värdebaserad vård som «en strategi för sjukvårdens styrning och arbetssätt som syftar till att åstadkomma så friska patienter som möjligt med en så låg resursåtgång som möjligt». Det var stor uppslutning från politiker, chefer och seniora läkare med anknytning till kvalitetsregister. Inom kort bildades en nationell satsning där många betydande landsting/regioner deltog.

Under det senaste året har det varit en polariserad och infekterad debatt mellan de som är för och de som är emot värdebaserad vård. Framförallt är det arbetet på Nya Karolinska sjukhuset som har fătt kritik för en allt för nära relation till konsultföretag BCG (Boston Consulting Group). Det har också ifrågasatts att mycket skattemedel läggs på en relativt obeprövad styrningsmetod.

Läkartidningen gör i början av 2017 ett försök att summera debatten och skriver att på Karolinska Universitetssjukhuset vill läkarföreningen stoppa införandet av värdebaserad vård. Men från andra platser i landet finns det ett flertal kliniker som uttrycker att man är positiv till den nya metoden (2). 
I en nyligen publicerad longitudinell intervju-studie har man följt de fyra

förbättringsgrupper som var piloter för införandet av Värdebaserad vård på Sahlgrenska

Universitetssjukhuset (3). De 20 projektdeltagarna intervjuades individuellt vid tre olika tillfällen med ca seks månaders mellanrum. Artikeln lyfter fram att begreppet «värde för patienten» skapat engagemang för förbättringsarbete. Begreppet har lyckats förena drivkrafter från vårdens kliniska professioner, vårdens chefer samt den politiska ledningen. Artikeln lyfter också fram vårdens komplexitet och det samexisterar många olika sätt att förstå begreppet «värde för patienten». Genom det longitudinella perspektivet på studien framträder hur vårdens olika professionella grupper, över tid, utvecklar sin egen förståelse om metoden. Att inkludera patienter i förbättringsgrupperna ingår i metoden. Genom att fråga patienter vad som är deras viktigaste resultat från vård och behandling, blev det tydligt att det som patienten värdesätter, inte alltid var det samma som man som vårdpersonal trodde patienten värdesatte. En ny artikel från samma forskargrupp summerar att värdebaserad vård haft positiv effekt hos några av de fyra pilotgrupperna, men metoden har inte fungerat hos alla (4). Studiens konklusion är att inte heller denna nya metod är ett mirakelmedel. Det centrala är att ledningen avsätter tid till medarbetare, att tillsammans med andra som berörs, arbeta fram lösningar till de problem man identifierar i det dagliga arbetet.

Tomas Tranströmer, Sveriges senaste nobelpristagare i litteratur, kan upplevas summera detta perspektiv i sitt poem Romanska Bågar (5): «Du blir aldrig färdig, och det är som det skall.»

LITTERATUR:

1. Porter ME, Teisberg EO. Redefining Health Care - Creating Value-Based Competition. Boston, MA: Harvard Business School Press, 2006.

2. Agerberg M. Värdebaserad vård: Omstridd metod på frammarsch. Läkartidningen 2017; 114: EFP7. http://lakartidningen.se/Aktuellt/Nyheter/2017/o1/Omstridd-metod-pa-frammarsch/(7.11.2017).

3. Nilsson K, Bååthe F, Andersson AE et al. Experiences from implementing value-based healthcare at a Swedish University Hospital - an longitudinal interview study. BMC Health Serv Res 2017; 17: 169. [PubMed][CrossRef]

4. Nilsson K, Bååthe F, Erichsen Andersson A et al. Value-based healthcare as a trigger for improvement initiatives. Leadersh Health Serv (Bradf Engl) 2017; 30:364- 77. [PubMed][CrossRef]

5. Tranströmer T. För levande och döda: dikter. Stockholm: Albert Bonniers Förlag, 1989.

Publisert: 28. november 2017. Tidsskr Nor Legeforen. DOI: 10.4045/tidsskr.17.0903

(C) Tidsskrift for Den norske legeforening 2020. Lastet ned fra tidsskriftet.no 